\title{
ZYGMUNT BAUMAN: CONCEITO DE MODERNIDADE LÍQUIDA E A CONTRIBUIÇÃO EPISTEMOLÓGICA NO ÂMBITO DO DIREITO DO TRABALHO DO CONCEITO DE LIQUIDEZ
}

\section{EDUARDO REINER}

Mestrando em Direito - Centro Universitário Curitiba - UNICURITIBA. Curitiba - PR. E-mail: eduardo.reiner@gmail.com

\section{RESUMO}

Zygmunt Bauman era um pensador contemporâneo que faleceu em 2017, sendo reconhecidamente um dos maiores pensadores do século $X X I$, ele trouxe e popularizou o conceito de Modernidade Líquida. Nesse contexto de liquidez as relações sofrem consequência direta produzindo e sendo produto desse estado fluídos das coisas, o foco dessa pesquisa será nas relações de trabalho. No mundo jurídico podemos também encontrar essa liquidez tratada por Bauman, o objetivo desse artigo é trazer a explicação de fenômenos jurídicos sob o ponto de vista da modernidade líquida do autor pesquisado, traremos como o autor define o conceito de modernidade líquida, apresentar alguns fenômenos jurídicos que entendemos pertinente e posteriormente mostrar essa relação entre o conceito do filósofo polonês e o direito. O ponto principal a ser estudado é o capítulo sobre o "trabalho" presente na sua obra mais conhecida: Modernidade Líquida. Trataremos da liquidez das atuais relações de trabalho, apresentando como se dava na modernidade "sólida" e na modernidade "líquida". Buscaremos mostrar a possível influência dessa última para o direito do trabalho, notadamente as reformas trabalhistas Espanhola de $2012 \mathrm{e}$ Brasileira de 2017. Inegável que as reflexões e contribuição de Bauman sobre a sociedade contemporânea e o conceito de liquidez que ele traz nos ajuda a entender os fenômenos jurídicos da atualidade, afinal o direito, mesmo que mais lentamente, 
Personalidade Acadêmica Homenageada:

Raymundo Juliano Feitosa (Universidade Federal do Rio Grande do Norte - UFRN)

segue as mudanças constantes nesse novo período histórico. Parece que essa liquidez veio para ficar até quando sobrevier uma possível crise profunda desse modelo. Quanto às relações de emprego, que ainda são a principal atividade humana, seria impossível pensar que elas e a regulação das mesmas ficariam de fora. A contribuição de Bauman se faz muito relevante para entendermos essa nova realidade precária, fluída e insegura das relações de trabalho, um contexto global que incorpora países como o Brasil e a Espanha, que a reboque da nova realidade e da exigência do capital se curvaram ao revogarem uma grande parcela dos direitos trabalhistas consolidados durante a modernidade "sólida".

PALAVRAS-CHAVE: Modernidade; Trabalho; Liquidez; Direitos.

\section{REFERÊNCIAS}

ARAÚJO, José Carlos E. Transformações no conceito de trabalho e sociedade pósindustrial. In: VIDOTTI, Tárcio José; GIORDANI, Francisco Alberto da Motta Peixoto (Coord.). Direito Coletivo do Trabalho em uma sociedade pós-industrial. São Paulo: LTr, 2003.

ARENDT, Hannah. A Condição Humana. Tradução de Roberto Raposo; Introdução de Celso Lafer. Rio de Janeiro: Forense-Universitária, 1987.

BAUMAN. Z. A sociedade líquida. São Paulo: Folha de São Paulo, 2003. Disponível em: https://www1.folha.uol.com.br/fsp/mais/fs1910200305.htm. Acesso em: $08 \backslash 01 \backslash 2018$

BAUMAN. Z. Amor líquido: sobre a fragilidade dos laços humanos. Rio de Janeiro: Jorge Zahar, 2004.

BAUMAN. Z. Modernidade líquida. Rio de Janeiro: Jorge Zahar, 2001.

CAPRA, F. O ponto de mutação. São Paulo: Ed. Círculo do Livro, 1982.

CASTEL, Robert. As metamorfoses da questão social: Uma crônica do salário. Petrópolis, Ed. Vozes, 1998.

CASTELLS, Manuel. A Sociedade em Rede. São Paulo, Editora Paz e Terra, 2007. 
Personalidade Acadêmica Homenageada:

Raymundo Juliano Feitosa (Universidade Federal do Rio Grande do Norte - UFRN)

DE MASI. Domenico. O futuro do trabalho: fadiga e ócio na sociedade pós-industrial. 1. ed. Rio de Janeiro: José Olympio, 2003.

EL PAÍS, Reforma trabalhista na Espanha: como recuperar os salários após cinco anos de queda. Madri: 2017. Disponível em: https://brasil.elpais.com/brasil/2017/07/04/internacional/1499157663_705701.html . Acesso em: 08\01\2018

ESTEVES, Juliana Teixeira; FILHO, Carlo Cosentino. O direito coletivo do trabalho na sociedade pósindustrial: desafios à recomposição da consciência de classe obreira. Revista Jurídica UNICURITIBA vol. 02, $\mathrm{n}^{\circ}$. 51, pp. 367-386. Disponível em: http://revista.unicuritiba.edu.br/index.php/RevJur/article/view/2814/371371481

GALBRAITH. John Kenneth. A anatomia do Poder. São Paulo. Edições 70, 2007.

International Monetary Fund(FMI), 2017. Disponível em (22/01/2018): http://www.imf.org/en/Publications/CR/Issues/2017/10/06/Spain-2017-Article-IVConsultation-Press-Release-Staff-Report-and-Statement-by-the-Executive-45319

KNOPFHOLZ, A.. A crise do positivismo na pós-modernidade. Revista Jurídica (FIC), v. 24,p.27-58,2010. Disponível em $<$ revista.unicuritiba.edu.br/index.php/RevJur/article/view/75>. Acesso em: $12 \backslash 12 \backslash 2017$.

LÚCIO, Clemente G. As reformas trabalhistas no mundo e as exigências do capital financeiro. Brasil em debate, 2017. Disponível em: http://brasildebate.com.br/as-reformas-trabalhistas-no-mundo-e-as-exigencias-docapital-financeiro/ Acesso em: 08\01\2018

SENNETT, Richard. A corrosão do caráter: consequências pessoais do trabalho no novo capitalismo. Rio de Janeiro: Record, 2004. 